\title{
The Effects of Splenectomy on Lipid Peroxidation and Neuronal Loss in Experimental Spinal Cord Ischemia/Reperfusion Injury
}

\author{
Deneysel Omurilik Iskemi/Reperfüzyon Hasarnda Splenektominin Lipit \\ Peroksidasyonu ve Nöronal Kayıp Üzerindeki Etkileri
}

Caglar TEMIZ1 ${ }^{1}$ Ilker SOLMAZ1 ${ }^{1}$, Ozkan TEHLI ${ }^{1}$, Serdar KAYA ${ }^{1}$, Onder ONGURU², Erhan ARSLAN ${ }^{1}$, Yusuf IZCI ${ }^{1}$

${ }^{1}$ Gulhane Military Medical Academy, Department of Neurosurgery, Ankara, Turkey

${ }^{2}$ Gulhane Military Medical Academy, Department of Pathology, Ankara, Turkey

Presented in: This case was presented as a discussion poster in the 23th Turkish Neurosurgery Society Scientific Congress 17-21 April, 2009. Girne, Cyprus.

Correspondence address: Ozkan TEHLI / E-mail: ozkantehli@gmail.com

\begin{abstract}
AIM: The aim of this study is to investigate the effects of prior splenectomy on oxidative stress and neuronal loss following spinal cord ischemia and reperfusion injury.

MATERIAL and METHODS: Twenty-one Sprague Dawley rats were randomly divided into three groups as sham laparatomy ( $\mathrm{n}=7$ ), spinal cord ischemia/reperfusion (SCIR) injury ( $n=7)$ and splenectomy+spinal cord ischemia/reperfusion (SSCIR) injury ( $n=7)$. In the latter group, splenectomy was performed 3 days before the SCIR injury. The activity of lipid peroxidation in the spinal cord was assessed by malondialdehyde (MDA), superoxide dismutase (SOD), glutathione peroxidase (GPx) and catalase (CAT) activities. The difference between the 3 groups was compared using Kruskal-Wallis test. The histological differences were assessed by counting the viable neurons.

RESULTS: SCIR injury resulted in a decrease of tissue lipid peroxidation activities. There was statistically significance between the three groups $(p<0.05)$, but there was not any significance between the SCIR and SSCIR injury groups ( $>0.05)$. The number of viable neurons was higher in SSCIR group when comparing with SCIR group $(p<0.05)$.
\end{abstract}

CONCLUSION: SCIR injury affects lipid peroxidation in rats. Prior splenectomy does not attenuate lipid peroxidation, but prevents neuronal loss after SCIR injury.

KEYWORDS: Neuronal loss, Oxidative stress, Spinal cord ischemia, Splenectomy

öz

AMAÇ: Bu çalışmanın amacı, splenektominin, spinal kord iskemi ve reperfüzyon sonrası oluşan oksidatif stres ve nöronal kayıp üzerindeki etkilerini araştırmaktır.

YÖNTEM ve GEREÇLER: Yirmi bir adet Sprague Dawley türü rat rastgele sadece laparotomi grubu $(n=7)$, spinal kord iskemi/reperfüzyon (SCIR) grubu ( $n=7)$ ve splenektomi+spinal kord iskemi/reperfüzyon (SSCIR) grubu ( $n=7)$ olarak 3 gruba ayrıldı. Son grupta splenektomi iskemi/ reperfüzyon hasarından 3 gün önce yapıldı. Spinal korda lipit peroksidasyonun aktivitesi malondialdehit, süperoksit dismutaz, glutatyon peroksidaz ve katalaz aktivitesi ölçülerek tesbit edildi. Üç grup arasındaki fark Kruskal-Wallis testi ile karşılaştırıldı. Histolojik farklılıklar canlı nöronlar sayılarak karşılaştırıldı.

BULGULAR: SCIR hasarı doku lipit peroksidasyon aktivitesinde düşmeye neden olmaktadır. Lipit peroksidasyon ürünleri bakımından üç grup arasında istatistiksel fark olmakla birlikte $(p<0,05)$, SCIR ve SSCIR grupları arasında istatistiksel olarak fark yoktur.(p>0.05). Canlı nöron sayısı SSCIR grubunda SCIR grubuna göre daha fazladır. $(p<0,05)$.

SONUÇ: SCIR hasarı ratlarda lipit peroksidasyonunu etkilemektedir. Önceden yapılan splenektominin lipit peroksidasyonu üzerine etkisi yoktur, ancak nöronal kaybı önlemektedir .

ANAHTAR SÖZCÜKLER: Nöronal kayıp, Oksidatif stres, Omurilik iskemisi, Splenektomi 


\section{INTRODUCTION}

Spinal cord ischemia/reperfusion (SCIR) injury is a devastating condition. It may occur as a consequence of an existing vascular malformation, as a complication of thoracoabdominal surgery or following surgical or endovascular treatment of a vascular lesion (22). In the central nervous system, significant decrease in the blood flow results in energy failure and initiates a cascade of events leading to cell damage by the amplification of many pathways set in motion by ischemia (22).

The pathophysiologic mechanisms that underlie ischemic injury to the spinal cord have not been clearly elucidated. A decrease in spinal cord blood flow (ischemia) after aortic or spinal surgery causes hypoxia in the spinal cord and increases lactic acid, hypoxanthine, and lipid peroxide levels. After the increase of blood flow (reperfusion) in the spinal cord, oxygen that is needed for production of uric acid is supplied from hypoxanthine. During this period, free radicals are produced. These radicals react with the cellular lipids and mitochondrial membranes and produce lipid peroxides. The lipid peroxidation of membranes causes membrane and cell damage. This process is called "reperfusion injury" $(8,27)$. Free oxygen radical-induced damage has been implicated in "post-ischemic cell injury" and cell death, while free radical scavengers such as superoxide dismutase (SOD), catalase (CAT) and glutathione peroxidase (GPx) are associated with partial amelioration of ischemic injury (9). Recent reports indicate that inhibiting the inflammatory response to stroke enhances neurosurvival and limits expansion of the infarction (2). The immune response that is initiated in the spleen has been linked to the systemic inflammatory response to stroke, contributing to neurodegeneration. It is proven that spleen-derived mononuclear cells migrate to the site of vascular injury and reduce neointima formation (28). It is also demonstrated that migration and engraftment of systematically administered spleen-derived mononuclear cells can be visualized in the post-ischemic spinal cord (20).

It is demonstrated that the removal of the spleen significantly reduces neurodegeneration after ischemic insult (2). However, the role of splenectomy on the SCIR injury has not been studied yet. Removal of the spleen may possibly decrease the production of mononuclear cells, and thus hinder or relieve the inflammatory reaction secondary to SCIR injury.

In this study, the protective role of prior splenectomy on the SCIR injury was investigated by measuring the lipid peroxidation products and also by counting the viable neurons in the spinal cord samples.

\section{MATERIAL and METHODS}

\section{Animals and experimental design:}

After receiving approval from the ethics committee, 21 Sprague-Dawley rats weighting 220-250 grams were used in this study. All animal experiments were performed in accordance with the institution's criteria for the care and use of laboratory animals. Animals were randomized into 3 experimental groups as follows:

(1) Control group (laparatomy only): 7 rats

(2) Spinal cord ischemia/reperfusion group (SCIR) : 7 rats

(3) Splenectomy+Spinal cord ischemia/reperfusion group (SSCIR) : 7 rats

\section{Operation Technique:}

For the SCIR group, anesthesia was induced and maintained with intraperitoneal injection of ketamine $\mathrm{HCl} 50 \mathrm{mg} / \mathrm{kg}$. The skin was shaved and sterilized with $10 \%$ povidone-iodine solution. A midline laparatomy was performed and the viscera were reflected to the right. After the retroperitoneum was opened, the abdominal aorta was closed with a 50-g closing force clip just distal to the left renal artery for a period of 45 minutes as described in the relevant literature (3). Each animal underwent 45 minutes of spinal cord ischemia, with the clip removed for reperfusion just before closure. For the SSCIR group, the splenectomy was performed by making a 2 $\mathrm{cm}$ anterior midline incision. Using blunt forceps, the spleen (with accompanying blood vessels) was exteriorized through the incision. The blood vessels were tied off and ligated and the spleen was removed. The abdominal wall and skin incision were closed with sutures. SCIR was performed 3 days later. The rats were sacrificed randomly 24 hours after the SCIR using an overdose of pentobarbital and the spinal cord samples were obtained en bloc between $L 2$ and $L 5$ levels for biochemical and histological analysis. The same cord samples were used for both analysis. For the control group, laparatomy via anterior midline incision was performed and then the abdominal wall was closed with sutures.

The spinal cord samples underwent biochemical and histological examinations by researchers blinded to animal selection, surgical method, biochemical and histological analysis.

\section{Measurement of oxidative stress:}

Spinal cord tissue malondialdehyde (MDA), GPx, SOD and CAT measurements were performed as described previously $(1,4,10,21)$ to determine the oxidative status in the spinal cord specimens. The caudal part of the specimens obtained at surgical resection were used for the measurements.

MDA measurement: After the reaction of thiobarbituric acid with MDA, the reaction product was extracted in butanol and was measured spectrofluorometrically (excitation, $532 \mathrm{~nm}$; emission, $553 \mathrm{~nm}$; slit, $10 \mathrm{~nm}$ ). Tetramethoxy propane solution was used as standard. Thiobarbituric acid reactive substances levels were expressed in nanomoles per gram wet weight.

GPx measurement: $20 \mu \mathrm{L}$ of homogenated tissue samples were mixed with $980 \mu \mathrm{L}$ of reaction mixture composed of $50 \mathrm{mmol} / \mathrm{L}$ Tris buffer ( $\mathrm{pH} 7.6), 1 \mathrm{mmol} / \mathrm{L}$ of Na2 EDTA, 2 $\mathrm{mmol} / \mathrm{L}$ of glutathione, $0.2 \mathrm{mmol} / \mathrm{L}$ of nicotine amide adenine dinucleotide phosphate, $4 \mathrm{mmol} / \mathrm{L}$ of sodium azide, and 1000 $\mathrm{U}$ of glutathione reductase, and incubated for 5 minutes at $37^{\circ} \mathrm{C}$. Then, the reaction was initiated with $8.8 \mathrm{mmol} / \mathrm{L}$ of hydrogen peroxide and the decrease in nicotine amide 
adenine dinucleotide phosphate absorbance was followed at $340 \mathrm{~nm}$ for 3 minutes. Enzyme activity was reported in units per gram.

SOD measurement: Tissue samples were homogenized with Polytron homogenizer and diluted 1:400 with $10 \mathrm{mmol} / \mathrm{L}$ phosphate buffer ( $\mathrm{pH}$ 7). Then, $25 \mu \mathrm{L}$ of diluted homogenates were mixed with $850 \mu \mathrm{L}$ of substrate solution containing 0.05 $\mathrm{mmol} / \mathrm{L}$ xanthine sodium and $0.025 \mathrm{mmol} / \mathrm{L}$ 2-(4-iodophenyl)3-(4-nitrophenol)-5-phenyltetrazolium chloride in a buffer solution composed of $50 \mathrm{mmol} / \mathrm{L}$ 3-cyclohexylaminopropane sulfonic acid and $0.94 \mathrm{mmol} / \mathrm{L}$ EDTA (pH 10.2). Later 125 $\mathrm{mL}$ of xanthine oxidase $(80 \mathrm{U} / \mathrm{L})$ was added to the mixture, and the increase in absorbance was followed at $505 \mathrm{~nm}$ for 3 minutes against air. Phosphate buffer $(25 \mathrm{~mL})$ or $25 \mathrm{~mL}$ of various standard concentrations of superoxide dismutase (SOD) in place of the sample were used as blank or standard determinations. SOD activity was expressed in units per gram.

CAT activity was determined by the method described by Aebi (1). The principle of CAT activity was based on the determination of the rate constant $(k$, sec-1) or of the hydrogen peroxide decomposition rate at $240 \mathrm{~nm}$. Results were expressed as $\mathrm{kU} / \mathrm{g}$ of protein.

\section{Histopathological examination:}

Animals were killed 24 hours after production of SCIR in group 2 and 3, after laparatomy in the control group. The entire spine was harvested en bloc and the tissue samples were obtained at L2 through L5 levels. The most cranial part of the specimens obtained at surgical resection fixed in $10 \%$ buffered formalin for 4 to 10 days before they were embedded in paraffin for sectioning. Transverse sections were obtained and stained with hematoxylin and eosin (H\&E). Three slices were obtained from each spinal cord at $5 \mu \mathrm{m}$ thickness for histological examination. The sections were numbered by the laboratory technician in order to blind the investigator to the groups. Results were analyzed according to the codes given at the pathology laboratory. The architecture of the white and gray matter, vascular mash, and neuronal loss in the spinal cord were analyzed and photographed under the x40, and x100 magnifications. The qualitative analysis of each slide was done to increase the reliability of results. For the quantitative analysis, the viable neurons in the ventral part of gray matter for each slice were counted. The presence of two or more of the findings including intracellular edema, chromatolysis, nuclear hyperchromasia, loss of intracytoplasmic organelles, and/or pyknosis, even mild or moderate was analyzed and accepted as sufficient criteria for cellular disintegration. These cells were assigned as "damaged" or "dead" while the remaining as "viable" under light microscope. The number of viable neurons in each animal was taken as the average of 3 sections and expressed as median value.

\section{Statistical analysis:}

Results are defined as mean $\pm \mathrm{SD}$, median and range. Data collected during the experiment were analyzed using SPSS 15 for Windows. Comparison among groups was done with
Kruskal-Wallis analysis of variance and then Bonferrroni adjusted Mann-Whitney $U$ test was applied for the comparisons of the two groups. Differences with a value of $p<0.05$ were considered statistically significant.

\section{RESULTS}

\section{Effects on oxidative stress:}

Compared to control group, spinal cord tissue MDA, CAT and GPx levels decreased, and SOD activity increased in SCIR and SSCIR groups $(p<0.05)$. Decrease in MDA, CAT and GPx and increase in SOD activities in groups 1, 2 and 3 were compared.

The control group had the highest MDA levels $(5.99 \pm 1.97$ $\mathrm{nmol} / \mathrm{g})$, whereas the SCIR group had the lowest (3.85 \pm 0.6 $\mathrm{nmol} / \mathrm{g}$ ). When the MDA levels of the groups were compared with Kruskal-Wallis variance analysis, all of the results were statistically significant $(p=0.005)$. When the groups' MDA levels were compared using the post hoc Bonferroni adjusted Mann-Whitney $U$ test, the spinal ischemia group had lower levels than those in the splenectomy and sham operated groups but the differences were not statistically significant ( $p>0.05$ ) (Table I). GPx levels were the highest in the control $(11.7 \pm 2.25 \mathrm{U} / \mathrm{mg})$ and the lowest in the SCIR group (5.94 $\pm 1.5 \mathrm{U} / \mathrm{mg}$ ). When the GPx levels were compared using Kruskal-Wallis variance analysis, the results were statistically significant $(p=0.004)$. The differences between the SCIR group and the other groups were statistically significant $(p<0.05)$ when the groups were compared using the post hoc Bonferroni adjusted Mann-Whitney $U$ test however there was no significant difference between the spinal ischemia group and the earlier splenectomy group $(p=0.88)$ (Table II).

The SOD levels were at its lowest in the control group (22.08 $\pm 14 \mathrm{U} / \mathrm{mg}$ ) and the highest in the spinal ischemia group $(69.43 \pm 28.78 \mathrm{U} / \mathrm{mg})$. When the SOD levels of the groups were compared using Kruskal-Wallis variance analysis, the results were statistically significant $(p=0.005)$. But there was no significant difference between the spinal ischemia group and the prior splenectomy group $(p=1.00)$ (Table III). The prior splenectomy or SSCIR group had the lowest CAT Levels $(9.53$ $\pm 1.67 \mathrm{kU} / \mathrm{g}$ ), whereas the highest levels were observed in the control group $(52.79 \pm 11.88 \mathrm{kU} / \mathrm{g})$. The differences between the spinal ischemia and all other groups were statistically significant when the groups were compared using the Kruskal-Wallis variance analysis $(p=0.004)$. There was no significant difference between the spinal ischemia and prior splenectomy groups when compared using the post hoc Bonferroni adjusted Mann-Whitney $U$ test $(p=0.402)$ (Table IV).

\section{Histopathological examination:}

The numbers of viable neurons in the control group was 44 (42-49). This was significantly higher than the SCIR group $(p<$ 0.05 ). The number of viable neurons was significantly higher in SSCIR group (33 (29-36)) in comparison with animals in SCIR group (12 (9-14)) ( $P<0.05)$. In control (only laparatomy) animals, normal architecture of the white matter was 
Table I: MDA Levels of the Groups

\begin{tabular}{|l|c|c|c|}
\hline Group & Mean & Standard deviation & Min-Max \\
\hline Sham & 5.99 & 1.19 & $4.65-7.96$ \\
\hline SCIR & 3.85 & 0.58 & $2.93-4.45$ \\
\hline SSCIR & 4.05 & 0.57 & $3.39-4.45$ \\
\hline KWx & 10.626 & & \\
\hline Df & 2 & & \\
\hline P & 0.005 & & \\
\hline
\end{tabular}

Table II: GPx Levels of the Groups

\begin{tabular}{|l|c|c|c|}
\hline Group & Mean & Standard deviation & Min-Max \\
\hline Sham & 11.7 & 1.81 & $9.46-13.95$ \\
\hline SCIR & 5.94 & 1.01 & $4.72-7.44$ \\
\hline SSCIR & 6.95 & 1.37 & $5.68-8.36$ \\
\hline KWx & & & \\
\hline Df & 10.865 & & \\
\hline P & 2 & & \\
\hline
\end{tabular}

Table III: SOD Levels of the Groups

\begin{tabular}{|l|c|c|c|}
\hline Group & Mean & Standard deviation & Min-Max \\
\hline Sham & 22.08 & 1.02 & $9.66-36.08$ \\
\hline SCIR & 69.44 & 16.6 & $55.55-98.21$ \\
\hline SSCIR & 70.04 & 24.52 & $53.49-98.21$ \\
\hline KWx & 10.626 & & \\
\hline Df & 2 & & \\
\hline P & 0.005 & & \\
\hline
\end{tabular}

Table IV: CAT Levels of the Groups

\begin{tabular}{|l|c|c|c|}
\hline Group & Mean & Standard deviation & Min-Max \\
\hline Sham & 52.79 & 11.32 & $32.76-64.67$ \\
\hline SCIR & 11.52 & 1.95 & $8.2-12-9$ \\
\hline SSCIR & 9.53 & 1.35 & $8.2-11.2$ \\
\hline KWx & 11.187 & & \\
\hline Df & 2 & & \\
\hline P & 0.004 & & \\
\hline
\end{tabular}

completely preserved. In SCIR animals, the normal architecture of the white and grey matters was deteriorated. The glial cells were more concentrated in the white matter of the spinal cord, and nuclear hyperchromasia was present. Pyknotic neurons associated with intracytoplasmic hyperchromatic and basophilic clumps were observed. Some neurons had a cytoplasmic appearance of early chromatolysis and some of them were more degenerated and shrunk. Decreased number of Nissl substances was prominent in these cells. Within the hyperchromatic nuclei of these neurons, the nucleoli were not visible. Neuronal loss was obvious (Figure 1A,B).
In prior splenectomized or SSCIR group, general architecture of the white and gray matters was more preserved. The ependymal cells were well preserved. Cellular integrity of neurons with almost normal distribution of Nissl substances was usually preserved. A small number of neurons and glial cells with hyperchromatic nuclei were scattered over the normal cells with euchromatic nuclei and prominent nucleoli. Neuronal loss was limited. Figure 2A,B shows the light microscopic findings of the study groups. 


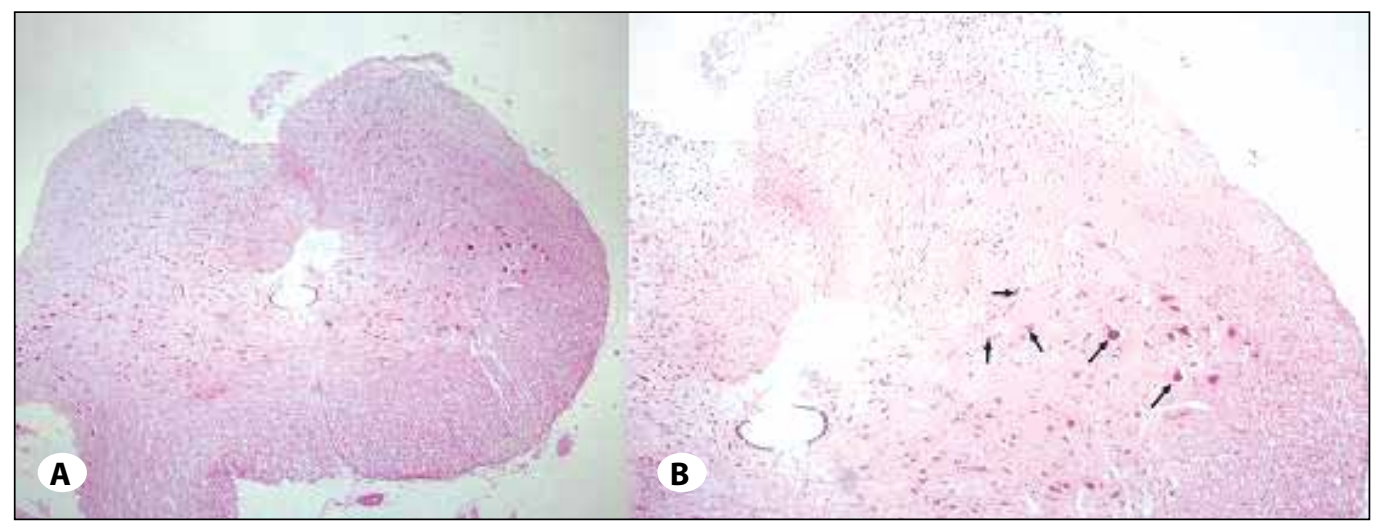

Figure 1: (A) Tissue sample from the spinal cord ischemia/reperfusion (SCIR) group exhibited massive neuronal loss especially in the ventral horn of the spinal cord (H\&E, X40). (B) Pyknotic neurons associated with intracytoplasmic hyperchromatic and basophilic clumps were observed. Neuronal loss was obvious. Long arrow shows viable neurons and the short arrows indicate the pyknotic neurons (H\&E, X100).

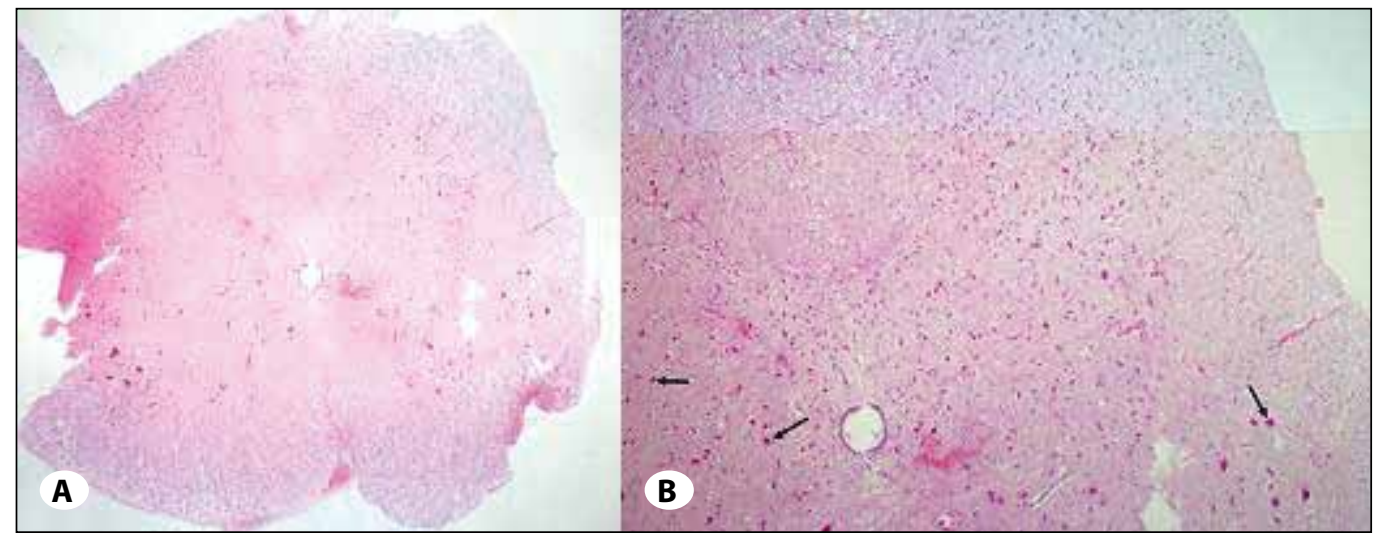

Figure 2: (A) Tissue sample from the splenectomy plus spinal cord ischemia/reperfusion (SSCIR) group revealed a small number of neurons and glial cells with hyperchromatic nuclei were scattered over the normal cells with euchromatic nuclei and prominent nucleoli. General architecture of the white and gray matters was more preserved when compared with SCIR group (H\&E, X40). (B) Neuronal loss was limited. The arrows show the viable neurons (H\&E, X100).

\section{DISCUSSION}

This study investigates the hypothesis that the splenectomy may play a protective role on the development of SCIR injury. Lipid peroxidation products were measured and viable neurons were counted in control, SCIR and SSCIR groups. Twenty-four hours after spinal cord ischemia, significant decrease in MDA, CAT and GPx levels and increase in SOD levels were observed in the spinal cord samples of SCIR and SSCIR groups. When the splenectomy was performed 3 days prior to the induction of ischemia, the changes in oxidative stress parameters were not statistically significant. The neuronal loss was low in the earlier splenectomized rats. The prior splenectomy did not affect the oxidative stress, but protected the neurons in the spinal cord of rats.

Spinal cord ischemia induces a complex series of molecular pathways involving signaling mechanisms, gene transcription, and protein formation. Free radicals and oxidative stress have been suggested to be involved in each of the steps in the injury cascade (16). After spinal cord ischemia, a series of metabolic processes ensue. Due to depletion of high-energy phosphate, cells in the ischemic area are subjected to waves of anoxic depolarization with hypoxic injury. Restoration of spinal cord blood flow with reoxygenation stimulates expression of adhesion molecules and chemokines, resulting in inflammatory reaction that involves recruitment of polymorphonuclear leucocytes, microvessel endothelial damage, hypoperfusion, and the "noreflow" phenomena, as well as apoptosis. So, SCIR injury initiates an inflammatory reaction in the spinal cord and the preventive procedures to reduce or stop this reaction may ameliorate the ischemia/ reperfusion injury.

Oxidative stress is the disturbance in the prooxidantantioxidant balance in favor of the former which leads to potential cellular damage. However it is difficult to measure the oxidative stress because of the presence of complex endogenous systems for correction and repair that quickly reduce the stress and limit the ability of testing methods to 
detect a change. DNA, lipid and protein oxidation products are the potential biomarkers to measure the oxidative stress that can result from a diminished antioxidant protection as well as increased free radical production. Therefore, investigating antioxidant depletion as a biomarker of oxidative stress may involve assessment of decreases in antioxidant concentrations or increases in their metabolites (6).

As mentioned above, spinal cord damage caused by ischemia and reperfusion is due, in part, to secondary injury from inflammation. Oxidative stress and inflammatory response occur in early periods of the spinal cord ischemia. Free radicals are involved in the oxidative injury which may cause enhanced lipid peroxidation (5). Lipid peroxidation can be defined as the oxidative deterioration of lipids containing any number of carbon-carbon double bonds (16). Lipid hydroperoxides are non-radical intermediates derived from unsaturated fatty acids, phospholipids, glycolipids, cholesterol esters and cholesterol itself. Their formation occurs in enzymatic or non-enzymatic reactions involving activated chemical species known as "reactive oxygen species" (ROS) which are responsible for toxic effects in the body via various tissue damages (12). Interest in the ROS (superoxide radical $\left(. \mathrm{O}_{2}\right)$, hydrogen peroxide $\left(\mathrm{H}_{2} \mathrm{O}_{2}\right)$ and hydroxyl radical $\left.(\mathrm{OH})\right)$ was increased after discovery of their critical role in many diseases. Their increased levels and decreased antioxidant defense can cause Deoxyribonucleic acid damage and a direct inhibition of proteins (7). The main target substrates for free oxygen radical activity are polyunsaturated fatty acids in membrane phospholipids, the modification of which result in disorganization of cell framework and function (23). The end product of these reactions is MDA. It is excreted in urine, blood, and other fluids and therefore serves as a marker of lipid peroxidation and the presence of oxidative stress respectively (18). Usul et al. demonstrated an increase in MDA following a spinal cord ischemia and reperfusion injuries, but, on the contrary, we observed a decrease in the MDA levels which was at its highest level in the control (sham operated) group and the lowest in the SCIR group. However, the difference between the SCIR and SSCIR groups was not statistically significant (27). So laparotomy and splenectomy may have played a role on the increase of MDA levels.

Deactivation and removal of ROS depends on the activity of antioxidant defensive systems including the following enzymes, SOD, CAT, and GPx (26). ROS can also be rendered harmless by nonezyme antioxidant defense including vitamins $A, C$, and $E$. SOD is the first line of defense against ROS and is active in catalysing detoxification of superoxide radical $\left(\mathrm{O}_{2}\right)(11) \cdot \mathrm{H}_{2} \mathrm{O}_{2}$ that's generated in this reaction is restored to water in the presence of CAT and GPx. Alternatively, CAT can catalyze the peroxidation reaction. CAT, in the presence of oxidative stress, is the most adaptive antioxidant enzyme and plays a significant role in the cell defense against oxidative damage (19). SOD is the most abundant antioxidant enzyme in animals. In our study, SOD, CAT and GPx levels were different among the 3 groups, but the difference between the SCIR and SSCIR groups was not statistically significant. GPx and
SOD activities were increased minimally and CAT decreased in the SSCIR group. But this is not statistically significant when compared with the SCIR group. These results showed that splenectomy did not significantly effect the oxidative stress which occured after the SCIR injury.

In medical practice, particular emphasis is currently being placed on the spleen because of its immune, filtering and hematopoietic roles. In addition to these functions, its protective role against ischemia and reperfusion injuries of the organs is receiving increasing attention (24). Some experimental studies have evaluated the possible protective effect of the splenectomy against the ischemia and reperfusion injury of the organs and some theories have been proposed to explain the possible mechanisms implicated in the protection of the organs. Carbon monoxide (CO) has been demonstrated to function as a gaseous molecular messenger and neurotransmitter like nitric oxide (25). Heme oxygenase $(\mathrm{HO})$ is the rate-limiting enzyme in the degradation of heme to produce bile pigments and $\mathrm{CO}$. $\mathrm{HO}-1$, an inducible form of $\mathrm{HO}$, is well known as the $32 \mathrm{kd}$ heat shock protein which is induced by various stimuli, such as heat shock, ischemia, radiation and hypoxia (3). Splenectomy ameliorates hepatic ischemia and reperfusion injury by either reducing neutrophil infiltration, inducing stress related protein $\mathrm{HO}-1$, downregulating expression of liver proliferating cell nuclear antigen or reducing superoxide anion release into the hepatic sinusoids (13). Splenectomy also attenuated damage to multiple organs including lung, liver and kidney caused by intestinal ischemia and reperfusion injury.

Spleen is a major organ to participate in the clearance of red blood cells and heme released from haemoglobin may highly induce the $\mathrm{HO}-1$ expression in spleen. In normal conditions, high level of HO-1 expression is observed in spleen and Kupffer cells, responsible for processing senescent or damaged erythrocytes. When the spleen is removed, it appears that the brain and other organs, such as liver, may replace this function of spleen (13). Induction of HO-1 may specifically decrease the cellular heme (pro-oxidant) and elevate the bilirubin (anti-oxidant) levels. It is previously shown that the levels of HO-1 protein in the liver is gradually increased and peaked on 3 days after splenectomy (13). It was also proven that the splenectomy decreases neutrophil infiltration into the post-ischemic liver and diminishes reperfusion injury (15). Splenectomy also ameliorates the brain blood flow and $\mathrm{O}_{2}$ supply during exercise in ponies (17). Recently, it is hypothesized, but not proven, that the splenectomy may be a prophylactic treatment method for the cerebral ischemia (14). Therefore, we performed the splenectomy 3 days prior to the SCIR injury to allow enough time for the increase of $\mathrm{HO}-1$ level and to reduce the inflammatory response to the spinal cord ischemia/reperfusion injury.

\section{Limitations of study:}

This is an in vivo experimental study that demonstrated the effects of prior splenectomy on the spinal cord ischemia/ reperfusion injury and discussed the possible mechanisms. 
One limitation of this study is the lack of measurement of HO-1 level for each group. Although it may be difficult to attribute the neuron-preservation effect to splenectomy without measuring the $\mathrm{HO}-1$ level, we presumed that the over-expression of $\mathrm{HO}-1$ protein may protect ischemic spinal cord tissue from being further damaged and provide resistance to oxidative stress by maintaining homeostasis. The other limitation of this study is the lack of motor testing of the animals. Although SCIR injury results in motor dysfunction in various degrees among animals, these deficits were not unique for each animal. Therefore, motor tests are not reliable to evaluate the effects of splenectomy on an SCIR injury.

\section{Clinical implications:}

During the vascular surgeries related thoracic and abdominal aorta, the spinal cord is inevitably subjected to ischemia/ reperfusion injury. Medical treatment was initially designed to preserve the spinal cord; however it was usually ineffective to recover the neurological functions. In this in vitro study which mimics the clinical settings of the spinal cord ischemia and reperfusion injury, we demonstrated that prior splenectomy attenuates the neuronal loss secondary to ischemia. Splenectomy may be a prophylactic treatment option for patients who had previous stroke history or significant risk for stroke. Therefore, the present study may form a novel strategy for neuronal protection in the future.

In conclusion, after spinal cord ischemia, the expression of the oxidative stress parameters was significantly changed. This might contribute to the neuronal damage, which eventually leads to neurological dysfunctions. The changes in the expression of oxidative stress parameters were not significantly changed by prior splenectomy. However, splenectomy has reduced the neuronal loss after the spinal cord ischemia.

\section{CONCLUSION}

SCIR injury affects lipid peroxidation in rats. Prior splenectomy does not attenuate lipid peroxidation, but prevents neuronal loss after SCIR injury.

\section{ACKNOWLEDGEMENT}

We are grateful to Dr. Selim Kilic MD for statistical analysis of the data, and Dr.Ahmet Aydın PhD for biochemical studies.

\section{REFERENCES}

1. Aebi H, Wyss SR, Scherz B, Skvaril F: Heterogeneity of erythrocyte catalase II. Isolation and characterization of normal and variant erythrocyte catalase and their subunits. Eur J Biochem 48:137-145, 1974

2. Ajmo CT Jr, Vernon DO, Collier L, Hall AA, Garbuzova-Davis S, Willing A, Pennypacker KR: The spleen contributes to strokeinduced neurodegeneration. J Neurosci Res 86:2227-2234, 2008

3. Akagi R, Takahashi T, Sassa S: Fundamental role of heme oxygenase in the protection against ischemic acute renal failure. Jpn J Pharmacol 88:127-132, 2002
4. Aydin A, Orhan H, Sayal A, Ozata M, Sahin G, Isimer A: Oxidative stress and nitric oxide related parameters in type II diabetes mellitus: effects of glycemic control. Clin Biochem 34:65-70, 2001

5. Basu S, Hellberg A, Ulus AT, Westman J, Karacagil S: Biomarkers of free radical injury during spinal cord ischemia. FEBS letters 508:36-38, 2001

6. Blumberg J: Use of biomarkers of oxidative stress in research studies. J Nutr 134: 3188S-3189S, 2004

7. Chopra S, Wallace HM: Induction of spermidine/spermine $\mathrm{N} 1$-acetyltransferase in human cancer cells in response to increased production of reactive oxygen species. Biochem Pharmacol 55:1119-1123, 1998

8. Emmez H, Yildirim Z, Kale A, Tonge M, Durdag E, Borcek AO, Ucankus LN, Dogulu F, Kilic N, Baykaner MK: Anti-apoptotic and neuroprotective effects of alpha-lipoic acid on spinal cord ischemia-reperfusion injury in rabbits. Acta Neurochir (Wien) 152: 1591-1600, 2010

9. Erten SF, Kocak A, Ozdemir I, Aydemir S, Colak A, Reeder BS: Protective effect of melatonin on experimental spinal cord ischemia. Spinal Cord 41:533-538, 2003

10. Fu R, Zhao ZQ, Zhao HY, Zhao JS, Zhu XL: Expression of heme oxygenase-1 protein and messenger RNA in permanent cerebral ischemia in rats. Neurol Res 28:38-45, 2006

11. Gonzales R, Auclair C, Voisin E, Gautero H, Dhermy D, Boivin P: Superoxide dismutase, catalase and glutathione peroxidase in red blood cells from patients with malignant diseases. Cancer Res 44:4137-4139, 1984

12. Introduction to lipid peroxidation. Available at: http://www. cyberlipid.org/perox/oxid0002.htm. Accessed February 12, 2011

13. Ito K, Ozasa H, Yoneya R, Horikawa S: Splenectomy ameliorates hepatic ischemia and reperfusion injury mediated by heme oxygenase-1 induction in the rat. Liver 22: 467-473, 2002

14. Izci Y: Splenectomy may be a prophylactic treatment for cerebral ischemia? Med Hypotheses 75:347-349, 2010

15. Jiang H, Meng F, Li W, Tong L, Qiao H, Sun X: Splenectomy ameliorates acute multiple organ damage induced by liver warm ischemia reperfusion in rats. Surgery 141:32-40, 2007

16. Lombardi V, Valko L, Stolc S, Valko M, Ondrejicková O, Horáková L, Placek J, Troncone A: Free radicals in rabbit spinal cord ischemia: Electron spin resonance spectroscopy and correlation with SOD activity. Cell Mol Neurobiol 18:399-412, 1998

17. Manohar M: Regional distribution of brain blood flow during maximal exertion in splenectomized ponies. Respir Physiol 68:77-84, 1987

18. Marks DB, Marks AD, Smith CM: Oxygen Metabolism and oxygen toxicity. In: Velker J (ed), Basic Medical Biochemistry: A Clinical Approach. Baltimore MD: Williams \& Wilkins, 1996:327-340

19. Mates JM, Sanchez-Jimenez F: Antioxidant enzymes and their implications in pathophysiologic processes. Front Biosci 4:339-345, 1999 
20. McCarthy JE, Redmond PH, Duggan SM, Watson RW, Condron CM, O'Donnell JR, Bouchier-Hayes DJ: Characterization of the defects in murine peritoneal macrophage function in the early postsplenectomy period. J Immunol 155:387-396, 1995

21. Ohkawa $\mathrm{H}$, Ohishi N,Yagi K: Assay for lipid peroxides in animal tissues by thiobarbituric acid reaction. Anal Biochem 95: 351-358, 1979

22. Oruckaptan HH, Ozisik P, Atilla P, Tuncel M, Kilinc K, Geyik PO, Basaran N, Yuksel E, Ozcan OE: Systemic administration of interleukin-10 attenuates early ischemic response following spinal cord ischemia reperfusion injury in rats. J Surg Res 155:345-356, 2009

23. Patterson RA, Leake DS: Human serum, cysteine and histidine inhibit the oxidation of low density lipoprotein less at acidic pH. FEBS Lett 434:317-321, 1998
24. Petroianu A, Veloso DF, Alberti LR, De Souza Vasconcellos $\mathrm{L}$ : Plasma lipid alterations after total splenectomy, subtotal splenectomy and splenic auto-implants in rats.J Gastroenterol Hepatol 23(7Pt2):e221-224, 2008

25. Suematsu M: The heme Oxygenase-Carbon Monoxide System as a regulator of microvascular function. In Organ Microcirculation. Ishii $H$, Suematsu M, Tanishita K, Suzuki H (eds), A Gateway to Diagnostic and Therapeutic Interventions Part: 5, Tokyo: Springer, 2005:261-265

26. Todorova I, Simeonova G, Kyuchukova D, Dinev D, Gadjeva V: Reference values of oxidative stress parameters (MDA, SOD, CAT) in dogs and cats. Comp Clin Path 13: 190-194, 2005

27. Usul H, Cakir E, Cobanoglu U, Alver A, Peksoylu B, Topbas M, Baykal S: The effects of tyrphostine Ag 556 on experimental spinal cord ischemia reperfusion injury. Surg Neurol 1:45-54, 2004

28. Werner N, Junk S, Laufs U, Link A, Walenta K, Bohm M, Nickenig G: Intravenous transfusion of endothelial progenitor cells reduces neointima formation after vascular injury. Circ Res 93:e17-24, 2003 